\title{
Retraction Note to: Application of artificial neural networks for analytical modeling of Charpy impact energy of functionally graded steels
}

\author{
Ali Nazari ${ }^{1}$ \\ Published online: 17 August 2020 \\ (C) Springer-Verlag London Ltd., part of Springer Nature 2020
}

\section{Retraction Note to: Neural Comput \& Applic (2013) 22:731-745 https://doi.org/10.1007/s00521-011-0761-9}

The Editor-in-Chief has retracted this article [1] because it significantly overlaps with a large number of articles that were under consideration at the same time, including [2-4] and previously published articles, including [5, 6]. Additionally, the article shows evidence of peer review manipulation. The author has not responded to any correspondence regarding this retraction.

\section{References}

1. Nazari A (2013) Application of artificial neural networks for analytical modeling of Charpy impact energy of functionally graded steels. Neural Comput Appl 22:731-745. https://doi.org/10. 1007/s00521-011-0761-9

2. Nazari A, Azimzadegan T (2012) Prediction the effects of $\mathrm{ZnO} 2$ nanoparticles on splitting tensile strength and water absorption of high strength concrete. Mater Res 15(3):440-454. https://doi.org/ 10.1590/S1516-14392012005000057. Epub 07 June 2012

3. Nazari A (2012) Application of ANFIS for analytical modeling of tensile strength of functionally graded steels. Mater Res 15(3):383-396. https://doi.org/10.1590/S1516-143920120050000 38. Epub 05 Apr 2012

4. Bohlooli H, Nazari A, Kaykha MM (2013) Prediction microhardness profile of functionally graded steels by ANFIS. Neural Comput Appl 22:847-858. https://doi.org/10.1007/s00521-0110775-3

5. Nazari A, Khalaj G, Riahi S (2012) Application of ANFIS for analytical modeling of JIC of functionally graded steels. Math Comput Model 55(3-4):1339-1353. https://doi.org/10.1016/j. mcm.2011.10.013

6. Nazari A, Sedghi A, Didehvar N (2012) RETRACTED: Modeling impact resistance of aluminum-epoxy-laminated composites by artificial neural networks. J Compos Mater 46(13):1593-1605. https://doi.org/10.1177/0021998311421222

Publisher's Note Springer Nature remains neutral with regard to jurisdictional claims in published maps and institutional affiliations.
The original article can be found online at https:// doi.org/10.1007/s00521-011-0761-9.

\section{Ali Nazari}

alinazari84@aut.ac.ir

1 Department of Materials Science and Engineering, Saveh Branch, Islamic Azad University, Saveh, Iran 